\title{
The Role and Challenges of Education in National Development (The Nigeria Experience)
}

\author{
Ugbogbo Helen E. \\ Akwemoh Magdalene 0.
}

Department of General Studies Edo State Institute of Technology and Management Usen, P. M. B. 1104. Benin City, Edo State, Nigeria

Omoregie Charles B.

Department of Urban and Regional Planning Edo State Institute of Technology and Management, Usen, P. M. B. 1104. Benin City, Edo State, Nigeria

\section{Doi:10.5901/jesr.2013.v3n10p25}

\begin{abstract}
This research paper focused on the role and challenges of education in national development. It dwelt extensively on the factors that aids and fosters educational development, Nigeria being the case study in this regard. It further unravels the importance of education in the Nigeria experience stating categorically the dimensions in which education had impacted the Nigeria states with such areas as technological, Industrial, Health, law, Security and Agricultural etc. The research paper further gave a comprehensive analysis of the importance and developmental contributions of tertiary education in contemporary Nigeria society. The importance of education in Professionalism was also extensively overviewed that is, the contribution of education to man power development and labour force in Nigeria and the policy underlining the educational system. By and large this research paper equally look as the role of education in economic growth and development specifically the role of education in economic transformation, improved-living standard, social economic growth, political stability, infrastructural development, provision of basic amenities amongst others economic developmental variables. Societal realities governing the smooth administration of the education as it affects the civil service administration was also an integral parts of the research with a specific reference to the 1988 civil service reform. The dimensions in which education has deepened the Nigeria democratic experience was also inclusive in the research that is political and social transformation. Nigeria has within a short period witness tremendous growth in social progress, freedom of speech, freedom of association and amongst others human rights, all synonymous with the contribution of education. Finally, the project tries to ascertain the contemporary challenges confronting the educational development in Nigeria and conclusively profer solution and constructive recommendations.
\end{abstract}

Keywords: Education, National Development, Professionalism, Training, Deepening Democracy

\section{Introduction}

According to Uwadia (2010), Education in a broad sense is a process by which an individual acquires the many physical and social capabilities demanded by the society in which he/she is born into to function. It is to a nation what the mind is to the body, just as a diseased mind is handicapped in the coordination and direction of the bodily activities. Therefore, the single most significant complex of social - control tools for national development is found in the educational system be it formal or informal. 
Eduwen. (1999), asserts that, education is the process of acquisition of knowledge, that is, it involves the teaching and learning process.

Formal education in Nigeria date back to the British colonialism. In the pre-colonial and colonial era, the colonial master introduced reading, writing, arithmetic which was the beginning of formal education system in Nigeria. Before now, education was informal, that is apprenticeship system of acquiring knowledge. With the advent of the British colonialism there was a shift from the informal to the formal system of education. Soon after the Nigeria independence tertiary institutions for man power training and development were established by the Nigerian states. Consequently this led to the growth of the Nigerian professionalism.

The Nigerian education have had a tremendous impact on the Nigeria nation over the years this is evident in the growth and development of the Nigeria Civil service, Political system, Technological growth, Communication, Industrial growth, increase in Agricultural production, Medicine engineering as well as the harnessing of her national endowment.

All the aforementioned development witnessed in Nigeria were brought about by the growth and expansion of tertiary education were professional handling these different sectors in the Nigerian economy were trained. Soon after independence, there was the need for competent manpower in the Nigerian quest for development; consequently upon this the federal government embark on the establishment of primary, secondary and tertiary institutions.

\subsection{Importance of Education}

a. It must train the individual for a better appreciation of his own cultural traditions whilst at the same time equipping him with the ability to absorb new ideas, new information and new data for resolving the constantly changing problems of his environment;

b. It must train the individual to relate to and interact meaningfully with other individuals in the society and to appreciate the importance of effective organization for human progress;

c. It must develop the creative ability of individuals especially in the cultural and technological realms;

d. It must foster in the individual those values which make for good citizenship, such as honesty, selflessness, tolerance, dedication, hard work and personal integrity, all of which provide the rich soil from which good leadership is spawned. Obasanjo (2012)

However, Education in Nigeria has brought developmental gains to the nation especially in the area of self- reliance and the perfecting of her ingenuity inequality. Education has equally led to the production of personalities of intellectual's endowment in such areas as literature, music, creative art sculpture, carving among other things. With the global tread of educational advancement among nations it is hoped that in the nearest future Nigeria will be rated among developed countries of the world via light of education.

\subsection{Tertiary Education in Nigeria}

Tertiary Education in Nigeria in the post-independence era. The quest for manpower development led to the establishment of Colleges of Education were teachers were trained. Polytechnics were also established were practices were taught in so many fields especially in the area of Engineering and Technologies, all this contributed immensely to the development of Nigeria. Universities were also set up to cater for the massive production of professionals. The Nigerian labour force tremendously increased as a result of the establishment and sponsorship of education by the federal government. All these enhanced bi-lateral relationship with other nations as well as enhanced her domestic and international trade to mention but a few, education was indeed the bedrock that led the transformation of the Nigerian state. Taiwo (1980)

\subsection{Education and Professionalism In Nigeria:}


The Nigerian states is characterised by professional from all works of life who are trained by virtue of the provision and gains brought about by education. The Nigeria Civil Service is largely populated by these professionals who contribute immensely towards the growth and development of Nigeria. The educational system of Nigeria had brought radical transformation to the Civil Service by virtue of in-service training for officials in the civil service hence there has been increased productivity in all spheres of the Nigeria economy. The Nigeria education system has led to the massive production of industrialist from all spheres of life as well as enhancement of the philosophical frame work of the Nigeria labour congress. As a matter of fact Nigeria is fast becoming an enviable icon in the area of Civil Service administration. The philosophical ideology and framework of the Nigeria Civil Service is structured on the rudiments and tenets of the national policy on education. This policy has the following as its cardinal goals. Igbuzor. $O$ (2006).

a. A free and democratic society.

b. A just and egalitarian society.

c. A united, strong and self-reliant nation

d. A great and dynamic economy.

e. A land full of bright opportunities for all citizens

From the forgo, the contribution of education to the development of the Nigerian state cannot be over-emphasized. Education has brought the dawning of new era of professionalism to all ministries and parastatal across the country. Furthermore, it has strengthened the intellectual requirement associated with the modern labour market.

\section{The Role of Education in National Development: The Nigeria Experience}

\subsection{The Role of Education in Economic Growth and Development:}

Nigeria is indeed a centre for world commerce and industry judging by virtue of her seaports, Tourist Centres, Parks etc. To adequately mastermind the requirement of this natural endowment the federal government embarked on the training of engineers and environmentalist to harnessed these natural resources with the establishment of department of engineering in universities and polytechnics. There has been a massive production of engineers who have contributed their knowledge and skills towards the growth of Nigeria. The Nigerian domestic policies have actualised its goals and objectives by virtue of the advantageous position played by education. With the use of policies and recommendation by professionals there has been adequate management of Nigerian domestic and international relations with other countries leading to improved leaving standard, social economy growth, political stability infrastructural development, provision of basic amenities social reconstruction etc with the increased demand for education there has been a continuous drive for a better leaving condition and way of life thus bringing about modernization and sophistication to the ordinary man. All these are the interplay of education. Soon after independence, in the advent of formal education there was a shift from traditional to formal approach of life, education has indeed transformed the traditional setting of Nigeria into a more completes entity. As a matter of fact education is the basic factor that necessitate all the aforementioned development. The Sub Sahara Africa, in Nigeria in particular, education remains the instrument for the emancipation of the populace from the ravaging effect of the deepened poverty, social injustice, economic meltdown, malnutrition, insecurity and all such social vices that have be devilled the Nigerian economy. It follows therefore that education remains the most potent indices for transformation of the society as well as the actualization of the yearning and aspirations of the people.

\subsection{Education and Civil Service Administration in Nigeria:}

Immediately Nigeria gained her independence, she was faced with the enormous responsibility of 
administration and governance, this led to the creation and establishment of departments and ministries in the three geographical region. Ever since, it has been a bottle neck and problematic issue to successfully administer the civil service. There has been series of reformation in the civil service with all aimed at attaining excellence in service delivery. However, with the advent and establishment of tertiary institutions across Nigeria the enormous challenge that be-devilled the civil Service has been drastically reduced as a result of massive production of university graduates. This is one of the most strategic areas were education has brought Nigeria to lime light in both domestic and international arena. With the professional expertise resulting from educational expansion in Nigeria the problem hitherto associated with the civil service has been drastically reduced over the years. Much of the bulk of the recommendations of the 1988 civil service reformation were educationally inclined and structured by administrative professionals from the tertiary institutions therefore, it is evident that education is a tool for societal emancipations, equity and justice, public sensitization and other developmental initiatives Edigin (2006).

\subsection{Education as a Tool for Deepening Democracy}

Education should ideally liberate one from the corrupting shackles of greed and graft, from the basal influences of primitive superstition, of ethnic and religious bigotry and from the corrosive instincts of selfishness and parochialism. Good wholesome education strives for excellence over mediocrity and promotes the patriotic spirit in place of blind sycophancy good wholesome education should place high premium on truth, justice, individual and social morality, as well as peace making. Good whole education should be education in leadership, the type that would throw up the leader as servant, mentor, inspirer and visionary. Good, wholesome education should emphasize civic and political awareness, training in human dignity and fundamental human rights and citizen responsibilities. Good, wholesome education should encompass training in the democratic culture and in popular participation in governance. Good, wholesome education today should include training in healthy living, ecological justice and environmental sustainability.

"Higher education can play a vital role as we work together in common cause to consolidate those gains, to strengthen institutions, to fight repression, to promote good governance. The power of education is integral to spreading peace and deepening democracy. When people participate in the democratic process and become engaged, they build peace, day by day, year by year".www.un.org/News/Press/doc/2011/sgsm13799.doc.htm)

The recent democratic experience that has been witnessed in Nigeria is by and large a biproduct of education in Nigeria. Democratic philosophies governing the Nigerian democratic system has been sustained and structured on principles of educations as shown in public enlightenment, sensitization, work shop, seminars-all being medium through which education have advanced the philosophy and ideology of education. Education has indeed strengthened the democratic stability in Nigeria. At the grass root level education have impacted the gains of democracy on local government administration, with the resultant effect of growth and development of local governments. The state and the federal government have equally experienced growth and development arising from democracy with education playing tremendous role. Before now the military dictatorship heightened Nigeria underdevelopment however, with the dawn of a new erademocracy, there was a reversal of this trend. Nigeria is fast becoming one of the most viable economy in the world by 2020 international speculations and education is the means by which the realization of this dream can come true. UNESCO (2006), UNAIDS (2008). The furtherance of the philosophical ideology and framework of education will help to foster the continuity of advancement realities. In a nutshell education has been the credo of civilization for the African nations since their independence with Nigeria inclusive. It is hoped that in the nearest future education in Nigeria will be embraced by all and this will go a long way in bringing Nigeria to the forefront of global development. Education should be a mandatory prerequisite for all youths in Nigeria and timing age groups up to the age of schooling. With the attainment of this radical economic initiatives the 
Nigeria society will encounter speedy progressive, economy, social, political and social transformation in short education is the key to unlocked the doors of social progress.

Before the advent of educational boom in Nigeria, the military dictatorship was galvanized and impoverished with dictatorship and brutality all arising from illiteracy. However, with the illumination of educational advancement the trend had change over the years with the arrival of democratic governance. Nigeria has within a short period witnessed tremendous growth in social progress, freedoms of speech, freedom of association, freedom of movement and other human rights that were hither to bastardized before the era of democracy. Education remains the only tool within which the practice of democracy can be perfected and it remains the only weapon with which such perfection can be sustained.

\subsection{The Challenges of Education in National Development}

Olekede, (2004) assert that the educational sector of the Nigeria economy has been bedevilled by series of challenges that has hitherto poses the great limitations to the actualizations of the cardinal goals and objectives for educational programmes. Obasanjo (2012) opined that At present, our education environment and the outlook for education in Nigeria are bedevilled with many problems, some of which appear intractable and are like recurring decimals. However, below are the challenges of Education in National Development:

\subsection{Inadequate Funding of Tertiary Institutions by the Federal Government:}

With the continuous increase in the population of students in tertiary institutions, it is obvious that the facilities needed for educational programmes in schools have increased over the years bringing about a drastic Increase in the course of providing a befitting education: for the Nigerian child. The funding of education is the responsibility of the government and the Nigerian government have embarked on strategic initiative to actualize the accomplishment of their societal need but the effort of the government have indeed yielded little or no result in bringing the Nigerian educational system to lime light. There is a gross inadequacy of educational funds required in the provision of educational infrastructures and facilities. Enormous fund is required in the refurbishment of dilapidated institutional infrastructure. With the advent of global and modern educational challenge the task of funding education in Nigeria is fast becoming unrealistic with insurmountable complexities. There has been shortage of funds for the implementation of educational policies and programmes thus making the Nigerian educational system incapable of meeting the challenges and demand of the $21^{\text {st }}$ century. With the down of the millennia dispensation and the natural resource with which Nigeria is greatly endowed it is hoped that in the near future the aforementioned problem would be a thing of the past. Olekede,(2004). .

\subsection{Shortage of manpower requirement:}

The shortage of manpower need an expertise in educational institution across the country has been one major set back an the Nigerian educational system there is shortage in the number of professional teachers. The technical schools and colleges as well as universities brought about inadequate training of professional graduates in the tertiary institution.

\section{Conclusion}

In taking up Nigeria's serious developmental challenges in education, our leaders must first acknowledge the need to develop a coherent policy that will promote self reliance; a visionary policy that identifies and highlights core national values that becomes standard irreducible courses in our institutions. Our education must go beyond mere literacy to take up the challenges of 
research and development in the modern world. Our education planners must constantly advocate for adequate budgetary allocations for equipping our schools with men and materials enough to meet the UNESCO's minimum national budgetary level of $25 \%$ for education. Our Education planners must set up quality standard education (www.georgeehusani.org).

In conclusion therefore, one would be right to say that education is the bedrock and building blocks for societal transformation and for the sustenance of any meaningful development. Education is the sustaining base of world political and social economy progress. It is hoped that in the near future education will bring greater technological and scientific transformation to the Nigerian nation. With this optimism education will gain a wider acceptance to the generality and to the Nigerian people/

\subsection{Recommendations}

The conclusive policy recommendations for this paper research are as follows:

1. The government school enforce the implementation of the policies of universal basic education programme.

2. The government should embark on a strategic reform on the funding of tertiary institutions

3. The government should embark on sponsorship of individuals who may wish to embark on educational programmes.

4. The government should shoulder sponsorship of tertiary education in Nigerian in order to ensure the massive production of skilled labour force in Nigeria.

\section{References}

I gbuzor, 0 (2006) "The State of Education in Nigeria"Action Aid International Nigeria. A keynote address at a roundtable organized by Civil Society Action Coalition on Education for all (CSACEFA) on 3rd July, 2006

Jegede, O. (2005). "Education in Nigeria in the 21st century". A keynote address at the Conference on Education in Nigeria in the 21st century organized by the School of Continuing Education, University of Uyo 17-19 August

Lar, M. N (1997) "Principles and Methods of Teaching. Application to Nomads. J os: Fab Education Books

Obani, T.C. (1996) "The Vision and Mission of Special Education in Nigeria". A lead paper presented at National Commission for Colleges of Education, (NCCE) at the National Conference, NTI, Kaduna, 21st -25th July

Olekede, N.O. (2004). Foundations of Education. Osogbo Sociological: Femprint Publisher.

Osokoya I. O. (2008). Contemporary Issue in History and Policy on Education in Nigeria. Ibadan: Laurel Educational Publishers Ltd.

Osuji, U.S.A \& Salawu, I. O. (2006). Revitalization of Our Educational System Through the Open and Distance Learning Mode. African journal of Historical Sciences in Education Vol. 2(1), 174 -184.

Olusegun Obasanjo,(2012) "Education and Development" : A lecture delivered At the 2012 Graduation Ceremonies of University of Nigeria Nsukka, Nigeria, J anuary 26, 2012

Taiwo C. O. (1980). 'The Nigerian Education System": Past, Present and Future. Thomas Nelson (Nig) Ltd.

Uwadia Orobosa on January 21, 2010 at 1:12pm Community.vanguardngr.com/profiles/blogs/educationand-national

www.un.or/News/Press/docs/2011/sgsm13799.doc.htm 